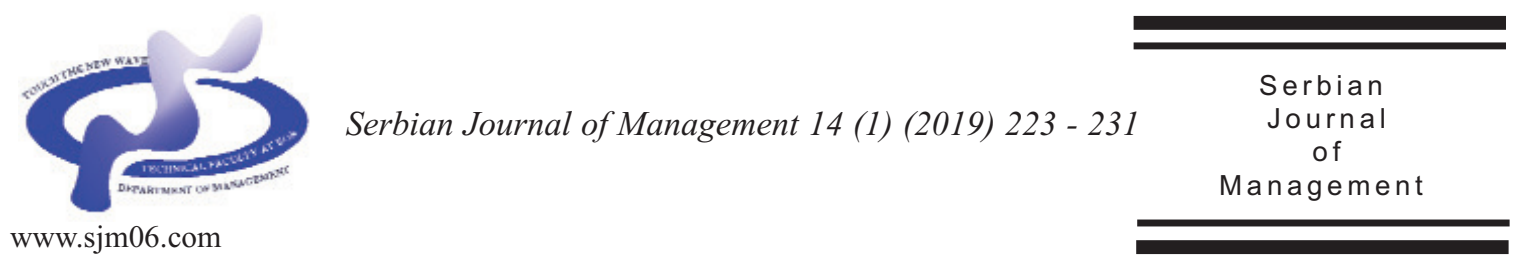

\title{
COMPENDIUM: KNOWLEDGE ECONOMY PRACTICES IN THE WORLD OF INFORMATION TECHNOLOGIES
}

\author{
Yann Pierre Donon \\ Samara University, Moskovskoe Shosse 34A, 443086 Samara, Russia
}

(Received 26 September 2018; accepted 07 March 2019)

\begin{abstract}
This paper treats the positioning of top level management towards the Information Technology (IT) departments in a company at the age of cloud computing. The conceptual knowledge needed by the management to make profitable decisions regarding IT, take financial opportunities of professional clouds technologies, what to take in account for a migration towards a new infrastructure and what tools can be used for realistic costs estimation will be overseen. This is paper is addressed not to technicians but decisional chains having little or no knowledge about cloud and general IT technologies, needing to make strategic decisions or needing to get a better understanding over their IT environment.
\end{abstract}

Keywords:information technologies, cloud computing, financial aspects

\section{INTRODUCTION}

The cloud is nowadays one of the most spoken-off pieces of the internet. Cloud technologies are booming and every day new applications are born on this support (Shende, 2014). Yet it is a very obscure subject for many, especially people having specializations far from Information Technologies (IT), it is referred here to companies' top level management, whether they are in charge of financial sectors and budget for large institutions, have to make strategic decisions as heads of start-ups regarding the development of their IT. This lack of knowledge is a major break for its adoption. It is especially true from decisional management chains that are not trained to what still is a new technology (Senarathna et al., 2018). Massive changes in the IT sphere being forecasted in the upcoming years, it is now necessary to get those layers of management into decisional processes by informing and involve them (Lambert,

\footnotetext{
* Corresponding author: yann.donon@ssau.ru
}

DOI: $10.5937 /$ sjm14-18987 
2018). To contribute in the cloud's spreading, this article provides a short overview of the topic of the cloud and its technologies in the context of knowledge economy. It describes expected infrastructural and personal changes involved by a migration of IT infrastructure to the cloud. The paper will give an overview of existing technologies, potential benefits of their adoption and anyone, after reading it, should understand the stakes of those technologies and their use.

\section{THE TECHNOLOGIES}

Often referred as "the cloud", cloud computing is remotely accessed computing capabilities. Technically, it means that some servers (powerful computers designed to work night and day and run all kind of applications) are available to users, often over the internet. Those servers provide not only storage capacities (ICloud, Dropbox, OneDrive) (Cheng, 2017), as it is often believed, but also access to all kind of applications and services used by IT professionals to deploy and manage infrastructures. That paper develops what those services represent in the context of knowledge economy.

Knowledge economy is defined as "...the use of knowledge to generate tangible and intangible values", it has always been a subject strongly linked to information technologies (Keith, 2002). The key holders in those technologies are often if not always the developers of different solutions. Those key holders used for a very long time traditional knowledge economy channel, through expert advisory, courses, or direct support. They now also not only develop new technologies but "hosts" (hosting is the action of storing an application or data on a server so that it can be accessed at any time) them and make them accessible through the cloud as applications Difference being that those applications are not installed or "hosted" on our computers or in our companies anymore, but in super facilities owned by the developer of the solutions and accessible through the internet. This represent several advantages as a reduced need of on-site IT infrastructures and personal (Marešová \& Půžová, 2014; Ubisoft, 2018), a more direct access to qualified support, a fully-integrated environment (every solution being usually offered on the same platform), an outsourcing of the risks (data losses, system breakdowns), a higher scalability to the needs of the company at a given time. All of those potential benefits being at the cost a higher dependence to solution's developers. This dependency is however not what really refrains the spreading of clouded technologies. Often, they aren't adopted not because of empirical calculations and projection of benefits but lacks in diffusion of information about them and technology acceptance issues (Stieninger et al., 2014). It is therefore of the upmost importance, if migrating to the cloud is of a strategical interest to push toward its implementation. This impulse is often to be given by the management, as often change resistance can be emitted from technical staff.

\subsection{Infrastructure, costs and the cloud}

For those having to manage costs of an IT service, it is well known how not only the personal represents important spending, but also infrastructure. It is important at this point to make everyone aware of what the infrastructure represents. It is not only what 
end user see, computers left on desks, referred as the "front office" but also, in a very important part, servers. Any company needs servers for their employees to have computer accounts, storage spaces, sometimes also databases and web applications. Those servers must be in isolated, secured, ventilated, fireproofed room and the whole infrastructure must also be saved elsewhere, in case of major incident. Adding to it spare infrastructure for tests and the regular necessity of a material renewal and this represent a very important charge. Every cloud solutions provider offers calculators to compare pricing of their solutions and it is extremely difficult to make generalities as it depends about current situation of an IT infrastructure, goals, demands and many other individual parameters. However, as underlined in the next chapters, several independent studies implemented comparison method, some highlighting economies of up to $30 \%$, in infrastructural costs by switching to a clouded infrastructure (Deckler, 2016; Xue \& Xin, 2016).

\subsection{The providers}

As it is a growing market (Columbus, 2017), most of the largest actors of IT try to get involved in it; the most notable at the moment are Microsoft and their cloud "Azure", Google and the "Cloud Platform" and Amazon with their "Web Services" (Evans, 2017). They now serve thousands of companies around the world and what is the most interesting is that even companies such as Adobe, HP or Xerox, (Microsoft Azure) having a very strong IT implication relies on those actors for different services. None of those companies have been favored during the writing of this paper but are taken in their quality of cloud solutions providers only.

\section{WHAT ARE THOSE CLOUDED SOLUTIONS?}

Figure 1 shows the four main forms of IT services available.

Enterprise IT (or on premise IT), designate services entirely managed in the inside of a company;

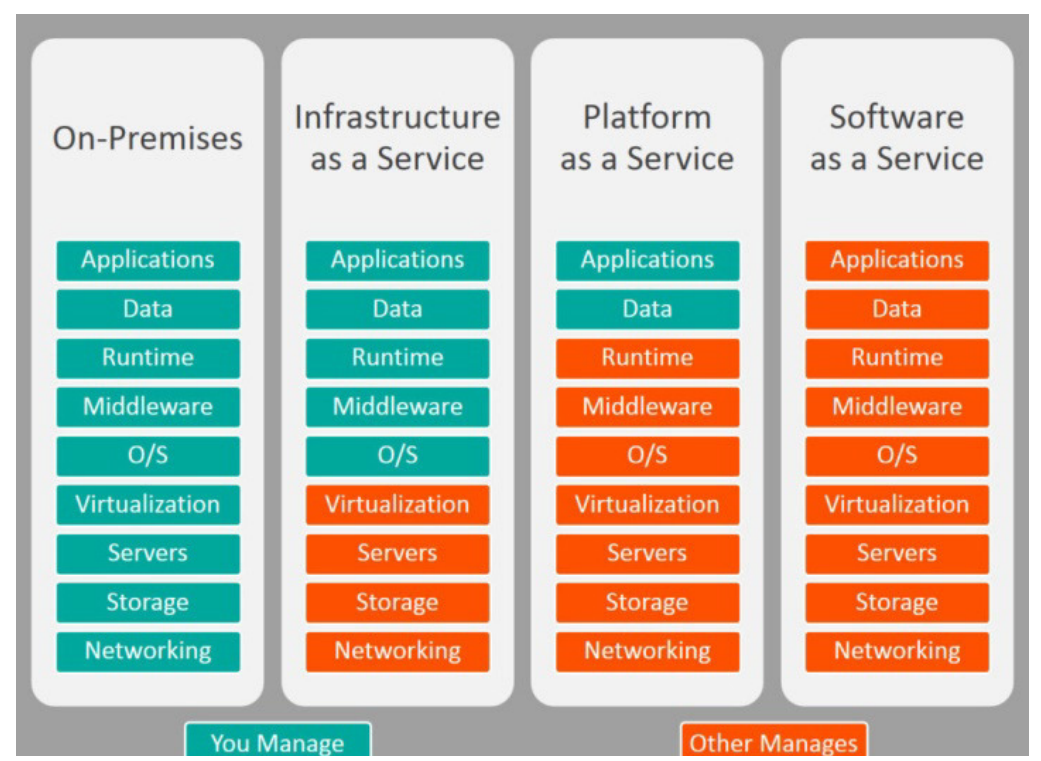

Figure 1. Diagram of the roles repartition if IT services (Stephen, 2017) 
Infrastructure as a Service (IaaS) are clouded solutions that suggest taking in charge all the physical part of the IT services;

Platform as a Service (PaaS) goes further than the previous one and offers complete environments where the only thing given to manage for the user in the final application;

Software as a service offers complete solutions with lower configuration possibilities, it is a final product and the client is nothing but a user.

Figure 1 represents the division of the most usual categories of infrastructures available, ordered by control from the product owner over the solution. Figure 2, compares it with cooking, from homemade pizza to pizza delivery. The Figure 2 was presented by Mr. Albert Barron in 2014 and became an explanation classic to compare those infrastructures.

Enterprise IT being the actual opposite of clouded solutions and Software as a service nothing but the delivery of a fully operational solution with no interventions from the final user's side it is too close from a traditional solution to be regarded in this article centered on knowledge economy. Therefore only both Infrastructure as a service and platform as a service solutions will be focused on here.

\subsection{IaaS}

IaaS, or Infrastructure as a Services answers to the need of outsourcing infrastructures. It addresses the need of the companies to stop having extensive local, back-office. Concretely, it means that if a company switches completely from an on premise to an IaaS solution, no servers, no room, will be needed anymore inside a company. In terms of costs, maintenance personal is not needed anymore after switching to a similar solution, however, the need of qualified personal for the

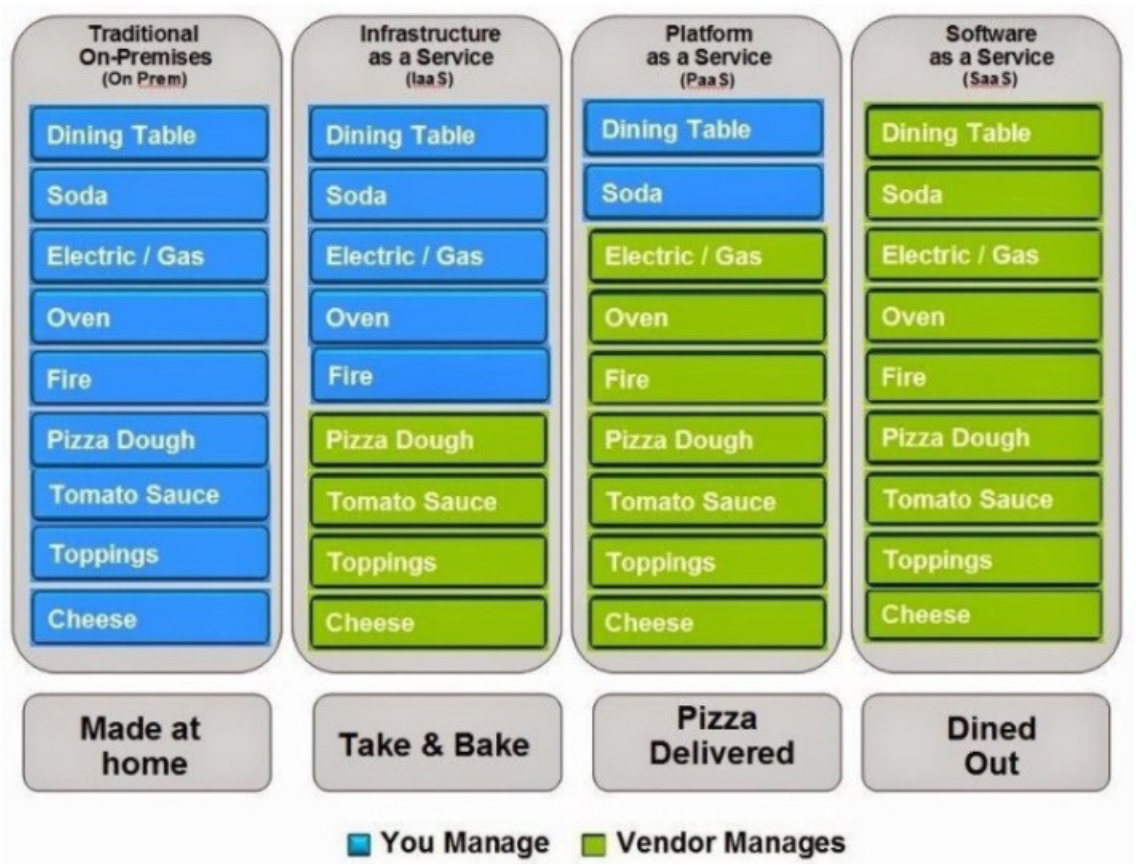

Figure 2. Pizza as a service, comparison between IT services and food delivery services (Kerrison, 2017) 
configuration and maintenance and systems is still the same. This solution may represent massive economies for a company, and still grants it almost total control over its infrastructure's technologies and functionalities (Deckler, 2016).

\subsection{PaaS}

PaaS, Platform as a service, is more complete that IaaS. It provides all the features IaaS would, but on the top of it also provides advanced tools. Those tools can for example be a directory service (a directory service is what allows all the employees of a company to use personal accounts on all computers of this company). They can be configured but offers slightly different and less possibilities than IaaS or on premise alternatives. Those systems being manage externally, their functionality, updates, security and maintenance is also guaranteed.

PaaS systems allows as they are simplified, managed and hosted externally, to greatly reduce not only the infrastructure maintenance workload but also the configuration and management workload, allowing redistributing technicians' time.

\section{TOTAL COST OF OWNERSHIP}

Clouded solutions are almost only "Payas-you-go" solutions. Meaning that unlike on premise solutions, they are scalable on demand (impacting directly the costs). As mentioned earlier, Total Cost of Ownership (TCO) varies significantly depending on the choices made and the environment. However, several studies exist on that matter:

- Fusion Alliance, an IT service company, evaluates the economies of a migration towards a fully clouded solution for a small company as high as $30 \%$, taking in accounts storage space, IT infrastructures and power. They ignore here the repercussion on the human costs implied by the reduced maintenance time and the automatizations provided (Deckler, 2016). Other studies also show that cost reduction is the most determining factor in the implementation of cloud solutions, one specifically ranked the most important criterion for the implementation of this technology as such: Cost reduction, flexibility, redundancy and reliability and scalability (Astri, 2015).

- The University of Hradec Králové, in Czech Republic did a similar evaluation, taking also in account factors as the availability of online services, the scalability (action of scaling a resource in accordance to needs at a given time), failure frequency, customer satisfaction and simplification of the management. Such factors have been highlighted by the Somerset County Council, Microsoft Azure's clients, in their customer case, along with the energy costs as determining in their choice of migration towards clouded infrastructure (sparing as much as 65 thousand pounds a year in energy only) (Somerset County Council, 2017). The study highlights the financial benefits as $37 \%$ on operating costs over 5 years, using Amazon EC2 services and a potential elimination of $21 \%$ of helpdesk calls (Marešová \& Půžová, 2014).

Cost calculation is however subject to many debates, as methods and the environment vary systematically and continuously. The context of a multi-billion market involving new-technologies with a high sentimental quotient also makes difficult to keep impartiality. It is however possible to make evaluations, 
Braunschweig's institute of IT management (Braunschweig Institut für Wirtschaftsinformatik), developed, among others, (Chang et al., 2016; Nanath \& Pillai, 2018) in 2012, a model oriented to management layers of a company to analyze benefits of a migration, considering financial and dynamic issues in their paper "Simulation Model for Cost-Benefit Analysis of Cloud Computing versus InHouse Datacenters"(Kristekova et al., 2012).

\section{CONSIDERATIONS}

Those technologies have, as mentioned before, the disadvantage to reduce the control of companies over their infrastructure. It appears essential to keep an access to on premise data on the form of a saves. Those are usually kept by default on computers and cloud solutions offers alternatives for a local save, meaning that a little effort is necessary for most on companies to compile to this condition.

Another issue that is of a major relevancy for the IT department is the compatibility to the existing IT services, some services being indeed not available over clouded solutions. They are however usually very specific solution, often developed in-house. Law might also represent a barrier as cloud has by definition no frontiers. European laws are now changing, reinforcing requirements on data protection and cloud providers reacted by offering to control territories of storage information. It is however a point that must be assessed in the migration towards a clouded infrastructure (Gonzalez et al., 2012; Ma, 2012; Vasiljeva et al., 2017).

\section{CONCLUSION}

For companies having a significant IT infrastructure, data protection, security and compatibility with the existing solutions are as many challenges for a migration toward a clouded solution. Moreover, such a migration can't be done in a day, it is a process and would a company choose to cloud entirely its infrastructure today, it would take many years before the last on premise server gets unplugged.

This paper highlights how infrastructures can be offered to create hybrid economically profitable solutions but services and platforms can also be included in hybrid software design. Using as an example the creation of face recognition software based on both on premise analysis and clouded services, thus reducing drastically the costs of the development of the technology while maintaining a low exploitation cost (Donon, 2018). This should serve as an example of how clouded solutions should not necessarily seen as a replacement but a new technology to be implemented and complete existing systems in order to make it more competitive, as intended with IaaS or PaaS solutions.

On a final thought, IT departments are often perceived as black-holes, transforming money into computer bugs. This feeling often comes from the incomprehension of those structures' responsibilities and makes their management difficult. In periods of poor economic climate, those departments are more than ever perceived as moneyconsuming. It is then the role of a company's decision maker to understand what assets are essential to an organization at a given moment. This evaluation is made difficult by this lack of knowledge of what is effectively done in those departments. This paper aims 
both to clarify some part of it and to suggest alternative possibilities to influence the cost of an IT department.

\section{Acknowledgment}

This article is a compendium of a lecture given at the international week on the theme of "Knowledge economy: challenges and opportunities" of the State University of Aerospace Instrumentation in SaintPetersburg, Russia.

\section{References}

Astri, L.Y. (2015). A Study Literature of Critical Success Factors of Cloud Computing in Organizations. Procedia Computer Science, 59, 188-194.

Barron, A. (2014). Pizza as a Service. Retrieved from Linkedin: https://www.linkedin.com/pulse/201407301 72610-9679881-pizza-as-a-service/

Chang, V., R.J., \&Wills, G.B. (2016). Organisational sustainability modeling- An emerging service and analytics model for evaluating Cloud Computing adoption with two case studies. International Journal of Information Management, 36(1), 167-179.

Cheng, Y. (2017, June). Cloud Storage Services. Finland: Centria university of applied sciences. Retrieved from: https://www.theseus.fi/handle/10024/132555

Columbus, L. (2017). Roundup Of Cloud Computing Forecasts, 2017. Retrieved from $\begin{array}{lllllll}F & o & r & b & e & s & \text { : }\end{array}$ https://www.forbes.com/sites/louiscolumbus /2017/04/29/roundup-of-cloud-computingforecasts-2017/\#284aeb31e872

Deckler, G. (2016). Cloud vs. on-premise costs, The critical factors every exec needs to consider. Fusion Alliance. Retrieved from: https://www.fusionalliance.com/wpcontent/uploads/2016/07/faCloudOnPremise sFoundations.pdf

Donon, Y (2018). Hybrid face recognition solution for security. CEUR Workshop Proceedings, 2210, 417-423.

Evans, B. (2017). The Top 5 CloudComputing Vendors. Retrieved from Forbes: https://www.forbes.com/sites/bobevans $1 / 20$ $17 / 11 / 07 /$ the-top-5-cloud-computingvendors-1-microsoft-2-amazon-3-ibm-4salesforce-5-sap/\#5f9cf4896f2e

Gonzalez, N., Miers, C., Redígolo, F., Simplício, M., Carvalho. T., Näslund, M., \& Pourzandi, M. (2012). A quantitative analysis of current security concerns and solutions for cloud computing. Journal of Cloud Computing: Advances, Systems and Applications, 1:11, 1-18.

Keith, S. (2002). What is the 'Knowledge Economy'? Knowledge Intensity and Distributed Knowledge Bases. Discussion Paper Series, United Nations University, Institute for New Technologies, Maastricht, Netherlands.

Kerrison, P. (2017). Pizza as a Service 2.0. Retrieved from Medium: https://medium.com/@pkerrison/pizza-as-aservice-2-0-5085cd4c365e

Kristekova, Z., Brion, J., Schermann, M., \& Krcmar, H. (2012). Simulation Model for Cost-Benefit Analysis of Cloud Computing versus In-House Datacenters. MKWI 2012.

Lambert, S. (2018). 2018 SaaS Industry Market Report: Key Global Trends \& Growth Forecasts. Finances Online. Retrieved from: https://financesonline.com/2018-saasindustry-market-report-key-global-trendsgrowth-forecasts/

Ma, S. (2012). A Review on Cloud Computing Development . Journal of networks, 7 (2), 305-310. 


\section{КОМПЕНДИЈУМ: ПРАКСА ЕКОНОМИЈЕ ЗНАҢА У СВЕТУ ИНФОРМАЦИОНИХ ТЕХНОЛОГИЈА}

\section{Yann Pierre Donon}

\section{Извод}

Овај рад се бави позиционирањем руководства на највишем нивоу према одељењима информационих технологија (ИТ) у компанији у доба рачунарства у облаку (eng. Cloud computing). Биће сагледано концептуално знање које је потребно менаџменту да донесе профитабилне одлуке у вези ИТ-а, искоришћавање финансијских могућности професионалних технологија облака, шта треба узети у обзир за прелазак на нову инфраструктуру и који се алати могу користи за процену реалних трошкова. Овај рад се не бави техничарима, већ ланцима одлучивања који имају мало или нимало знања о облаку и ИТ технологијама уопште, а требају донети стратешке одлуке или боље разумети своје ИТ окружење.

Кључне речи:информационе технологије, облак, економски аспекти

Marešová, P., \& Půžová, K. (2014). Application of the Cost Benefit Analysis method in Cloud Computing in the Czech Republic. Procedia - Social and Behavioral Sciences, 109, 674-678.

Microsoft Azure. (n.d.). Case studies. (Microsoft Azure) Retrieved September 11, 2018, from https://azure.microsoft.com/enus/case-studies/

Nanath, K., \& Pillai, R. (2018). A Model for Const-Benefit Analysis of Cloud Computing. Journal of International Technology and Information Management, 22(3), 92-117.

Senarathna, I., Wilkin, C., Warren, M., Yeoh, W., \& Salzman, S. (2018). Factors That Influence Adoption of Cloud Computing: An Empirical Study of Australian SMEs . Australasian Journal of Information Systems, 22, 1-31.

Shende, J.R.G. (2014). Cloud forensics. No. patent US 2014/0317681 A1. United States of America.

Somerset County Council. (2017).
County government boosts innovation and savings with cloud and open source. Retrieved from Microsoft: https://customers.microsoft.com/enus/story/somersetcountycouncil

Stephen, W. (2017). SaaS vs PaaS vs IaaS: What's The Difference and How To Choose. (Multi-Cloud Blog) Retrieved September 10, 2018, from https://www.bmc.com/blogs/saas-vs-paasvs-iaas-whats-the-difference-and-how-tochoose/

Stieninger, M., Nedbal, D., Wetzlinger, W., Wagner, G., \& Erskine, M.A. (2014). Impacts on the organizational adoption of cloud computing: A reconceptualization of influencing factors. Procedia Technology, $16,85-93$.

Ubisoft. (2018). Rainbow Six Siege uses Azure to deliver immersive multiplayer games globally. Retrieved from Microsoft: https://customers.microsoft.com/enus/story/ubisoft-media-telco-azure

Vasiljeva, T., Shaikhulina, S., \& Kreslins, 
K. (2017). Cloud Computing: Business Perspectives, Benefits and Challenges for Small and Medium Enterprises (Case of Latvia). Procedia Engineering, 178, 443-451. Watts, S. (2017). SaaS vs PaaS vs IaaS: What's The Difference and How To Choose. Retrieved from BMS Blogs: https://www.bmc.com/blogs/saas-vs-paasvs-iaas-whats-the-difference-and-how-tochoose/

Xue, C.T.S., \& Xin, F.T.W. (2016). Benefits and Challenges of the Adoption of Cloud Computing in Business. International Journal on Cloud Computing: Services and Architecture, 6(6), 01-15. 